\title{
Germination and vigor of Caesalpinia pulcherrima (L.) Sw. seeds under different light and temperature conditions
}

\author{
Magnólia Martins Alves ${ }^{*}$ (-) Edna Ursulino Alves² ${ }^{2}$ Luciana Rodrigues de Araújo \\ Maria de Lourdes dos Santos Lima ${ }^{2}$ Marina Matias Ursulino ${ }^{2}$
}

${ }^{1}$ Programa de Pós-graduação em Agronomia, Centro de Ciências Agrárias (CCA), Universidade Federal da Paraíba (UFPB), 58397-000, Areia, PB, Brasil. E-mail: magecologia@ $@$ hotmail.com. "Corresponding author.

${ }^{2}$ Departamento de Fitotecnia e Ciências Ambientais, Centro de Ciências Agrárias, Universidade Federal da Paraíba (UFPB), Areia, PB, Brasil.

ABSTRACT: Caesalpinia pulcherrima is a Fabaceae family species from Central America, which has a small size and is widely used as a living fence in the urban afforestation for streets, parks, and gardens. Based on this importance, the aim of this research was to study the influence of light and temperature on the germination of C. pulcherrima seeds. The study was carried out at the Laboratory of Seed Analysis of the Center of Agricultural Sciences of the Universidade Federal da Paraiba, Areia, PB, Brazil. The experimental design was completely randomized, comprising a $3 \times 5$ (three temperatures and five light regimes) factorial scheme with four replicates containing 25 seeds each. Germination and vigor of seeds were evaluated under temperatures of $25^{\circ} \mathrm{C}$ and $30^{\circ} \mathrm{C}$ constant and $20-30^{\circ} \mathrm{C}$ alternated in different light regimes: white, green, red-distant, red, and absence of light. Variables analyzed were: germination, first germination count, germination speed index, root length, shoot length, and the ratio of dry mass of root/shoot of the seedlings. Seeds of C. pulcherrima germinate in the presence and absence of light, being a neutral photoblastic. Recommendation to test the vigor of these seeds is the temperature of $30^{\circ} \mathrm{C}$ in the white light regime.

Key words: flamboyant mirim, photoblastism, vigor.

Germinação e vigor de sementes de Caesalpinia pulcherrima (L.)

Sw. Sob diferentes condições de luz e temperatura

RESUMO: Caesalpinia pulcherrima, pertence à família Fabaceae, é uma espécie exótica originada da América Central, apresenta pequeno porte, muito utilizada como cerca-viva em arborização de ruas, parques e jardins. Diante de sua importância o trabalho teve como objetivo estudar a influência da luz e temperatura na germinação de sementes de C. pulcherrima. A pesquisa foi conduzida no Laboratório de Análise de Sementes, do Centro de Ciências Agrárias da Universidade Federal da Paraíba, em Areia, PB, Brasil. O experimento foi conduzido em um esquema fatorial $3 x 5$ (três temperaturas e cinco regimes de luz) com quatro repetições, contendo 25 sementes para cada tratamento. Avaliouse a germinação e vigor das sementes sob temperaturas de $25^{\circ} \mathrm{C}$ e $30^{\circ} \mathrm{C}$ constantes e $20-30^{\circ} \mathrm{C}$ alternada em diferentes regimes de luz: branca, verde, vermelha-distante, vermelha, e ausência de luz. As variáveis analisadas foram: germinação, primeira contagem de germinação, indice de velocidade de germinação, comprimento de raiz/parte aérea e massa seca de raiz/parte área de plântulas. As sementes de C. pulcherrima germinam na presença e ausência de luz, sendo um fotoblástico neutro. A recomendação para testar o vigor dessas sementes é a temperatura de $30^{\circ} \mathrm{C}$ no regime de luz branca.

Palavras-chave: flamboyant mirim, fotoblastismo, vigor.

\section{INTRODUCTION}

Caesalpinia pulcherrima (L.) Sw. belongs to the Fabaceae family and is an exotic species originated from the Central America. It is commonly known as dwarf poinciana, "baio-de-estudante", "Flamboyanzinho", and flamboyant- "mirim". Fruits and seeds are produced abundantly throughout the year, being the seed the main way of propagation (LORENZI, 2009).

The species has been studied because of its easy growth and capability of producing large quantity of seeds (BRAGA et al., 2011). Seeds are considered an important guarantee of the survival for plants species.
Being mainly composed by embryo, endosperm, and tegument, and these organs are strongly influenced by environmental differences, such as temperature, light, and humidity (ABUD et al., 2010).

Temperature directly interferes with the physiological quality of the seeds and can act on the speed of water absorption and in the biochemical processes, thus affecting the percentage, speed, and uniformity of their germination (CARVALHO \& NAKAGAWA, 2012). According to the same authors, temperature and light are considered important environmental factors for the germination, because the temperature affects both the final percentage, as well as the speed of germination. 
For the germination of different species, it is recommended the use of a specific temperature and a type of ideal substrate, besides the light that may be required during this process (RIBEIRO et al., 2012). However, even though light is not considered an essential factor for the germination process, in non-dormant seeds, its presence may contribute to mitigate problems caused by low soil water potential and the effects of temperatures higher than optimal (MARCOS FILHO, 2005).

The action of this pigment depends on the type of incident radiation, since light with a high $\mathrm{red} /$ red-extreme ratio (V/LV) can induce it to take the active form (FVE), promoting the germination of photosensitive seeds (VÁZQUEZ-YANES \& OROZCO- SEGOVIA, 1990).

Knowledge of how environmental factors influence seed germination is extremely important. Thus, they can be controlled and manipulated in order to optimize the percentage, speed and uniformity of germination, resulting in the production of more vigorous seedlings for planting.

The knowledge of the requirements of germination is regulated by the interaction of its ecophysiological state and the environmental conditions. Then, the objective of this research was to evaluate the influence of light and temperatures on the germination and vigor of Caesalpinia pulcherrima L. seeds.

\section{MATERIALS AND METHODS}

\section{Place of experiment}

The experiment was conducted at the Laboratory of Seed Analysis, belonging to the Department of Phytotechny and Environmental Sciences of the Center of Agricultural Sciences, Universidade Federal da Areia, state of Paraíba.

Fruits were collected from mother-plants in the municipality of Areia, state of Paraíba. Afterwards, they were transported to the Laboratory of Seed Analysis for processing, where they were manually opened to get seeds, and subsequently submitted to determinations and tests as described below.

\section{Water content}

Water content of seeds was obtained by the standard method of the drying oven at $105 \pm 3^{\circ} \mathrm{C}$, according to the rules of the Brazilian Rules for Seed Analysis (BRASIL, 2009), with four samples of 10 seeds each, being results expressed as a percentage.

\section{Temperatures and luminosity}

For each treatment, 100 seeds were used, being divided into four replicates of 25 each. The test was carried out in seed germination chambers adjusted to the constant temperatures of 25 and $30^{\circ} \mathrm{C}$, and also alternated of $20-30^{\circ} \mathrm{C}$. Light regimes were white, green, red, far-red, and absence of light. In order to simulate the obtaining of light waves, cellophane paper was combined, and for the white light treatment, the germination tests were carried out under the normal laboratory lighting. For green light, seed rolls were wrapped with two sheets of green cellophane paper; to obtain the red light, two sheets of red cellophane paper were used, while for the far-red, the covering was made with three sheets of overlapped cellophane papers (red-blue-red), and the absence of light was obtained using black plastic bags. The regimes were 8 hours with light (daytime) and 16 hours without light (night time) and for the dark condition (total absence of white light).

\section{Germination test}

The forest species usually present the mechanism of dormancy, so it was performed a treatment to overcome this dormancy, by scarification with manual sanding using sandpaper $\mathrm{N}^{\circ} 80$ in the region opposite to the thread followed by the methodology of Oliveira et al. (2010).

For the germination test, 100 seeds were used, being divided in four replicates of 25 each, and distributed on two sheets of paper towel, covered with a third and organized in roll shape. The paper towel was moistened with distilled water in the amount equivalent to 2.5 times the mass of dry paper (BRASIL, 2009). The germination tests ending 14 days were performed in B.O.D germination chambers with controlled temperature and light.

\section{For the counting of germinated seeds}

For beginning at 6 days after sowing, it was considered as normal seedlings those that had emitted the primary root with the emission of the cotyledons.

\section{Index of germination speed (IVG)}

The index was calculated using the formula proposed by Maguire (1962). The criterion used in the evaluations was the normal seedlings with perfect essential structures (BRASIL, 2009).

\section{Root and shoot length of seedlings}

After the final germination test counts at 14 days after sowing, the normal seedlings of each treatment and the repetition had measured the root and shoot using a ruler graduated in centimeters, and results were expressed in $\mathrm{cm} / \mathrm{seedling}^{-1}$. 


\section{Dry mass of root and shoot of seedlings}

The same seedlings of the previous evaluation were placed in Kraft paper bags and taken to the oven set at $65^{\circ} \mathrm{C}$ until reaching constant weight (48 hours). After that period, the samples were weighed in an analytical balance with an accuracy of $0.001 \mathrm{~g}$, being the results expressed in $\mathrm{g} /$ seedling $^{-1}$.

\section{Experimental design and statistical analysis}

The experimental design was completely randomized, with treatments distributed in a $5 \times 3$ factorial scheme (light regimes and temperatures), using four replicates of 25 seeds each. According to the tests of normality and homogeneity of variances there was no need for data transformations. The data were submitted to analysis of variance and the means were compared by the Scott-Knott test up to 5\% of error probability, using the statistical program Sisvar $^{\circledR}$ (FERREIRA, 2000).

\section{RESULTS AND DISCUSSION}

The water content of the seeds of C. pulcherrima at the time of performing the experiment was $10 \%$. By the analysis of variance it was verified interaction between conditions of light and temperature for all the analyzed variables demonstrating that these are dependent.

Considering the factors alone, there was a significant difference at the $1 \%$ probability level for germination, first count, germination speed index, length area, root dry mass and except for shoot, with no significant difference for root length.

Seeds of $C$. pulcherrima germinated satisfactorily at the three tested temperatures $(25,30$ and $20-30^{\circ} \mathrm{C}$ ). Regarding the effects of light at each temperature, it was observed that at $25^{\circ} \mathrm{C}$ the highest germination percentages occurred under the light regimes of green, red, far-red, and dark; at $30^{\circ} \mathrm{C}$, it was under white, green, red, and dark lights; at 20$30^{\circ} \mathrm{C}$, the highest percentages of germination were under white, red, and far-red lights (Table 1).

However, the germination was not restricted just to light, since it also occurred in the dark, and can be a neutral photoblastic, showing that the seeds of $C$. pulcherrima can germinate not only in clearings, but also under the canopy of different strata.

For many species the presence of light favors the germination of the seeds, which in this case was not favorable to C. pulcherrima for germination, being able to consider at the first moment, that it could be considered negative photoblastic.

Therefore, when evaluating results, it was observed that at temperatures of $30^{\circ} \mathrm{C}$ and $20-30^{\circ} \mathrm{C}$
Table 1 - Germination (\%) of Caesalpinia pulcherrima under different light regimes and temperatures.

\begin{tabular}{|c|c|c|c|}
\hline \multirow{2}{*}{ Light cycles } & \multicolumn{3}{|c|}{----------Temperatures $\left({ }^{\circ} \mathrm{C}\right)-$} \\
\hline & 25 & 30 & $20-30$ \\
\hline White & $88 \mathrm{bB}$ & $98 \mathrm{aA}$ & $96 \mathrm{aA}$ \\
\hline Green & $95 \mathrm{aA}$ & $94 \mathrm{aA}$ & $84 \mathrm{bB}$ \\
\hline Red & $95 \mathrm{aA}$ & $94 \mathrm{aA}$ & $97 \mathrm{aA}$ \\
\hline Far red & $93 \mathrm{aA}$ & $85 \mathrm{bB}$ & $97 \mathrm{aA}$ \\
\hline Dark & $95 \mathrm{aA}$ & $99 \mathrm{aA}$ & $86 \mathrm{bB}$ \\
\hline
\end{tabular}

Means followed by the same letter, lowercase in the column and upper case in the row, do not differ statistically from each other, a $5 \%$ probability by the Scott-Knott test.

there was interference of white light on germination, allowing to infer that $C$. pulcherrima is indifferent to photoblastic however, because it receives a quantity of light in the moment of evaluation, it can be affirmed that the species studied is considered neutral photoblastic.

According to Barroso et al. (2010) studying Sinningia leucotricha, the luminosity and substrates promoted superior results when the seeds were in the presence of light. In seeds of Clitoria fairchildiana Howard, only in the dark condition at $25^{\circ} \mathrm{C}$, the germination was significantly lower considering light (ALVES et al., 2012). For the species Dalbergia cearenses Ducke, seeds submitted to treatments with a constant temperature of $45^{\circ} \mathrm{C}$ and alternated temperature of $20-45^{\circ} \mathrm{C}$ with 12 hours of light/12 of dark did not present a satisfactory germination (NOGUEIRA et al., 2014). Seeds of Murdannia nudiflora promoted greater germination when submitted to light and at temperatures of 25 and $30^{\circ} \mathrm{C}$ (LUZ et al., 2014). There was an interaction between the temperature and luminosity for the germination of Sinningia leucotricha (Hoehne) Moore (MORITZ et al., 2015).

Table 2 shows the results for the vigor of seeds evaluated by the first germination count, in which

Table 2 - First seed germination count Caesalpinia pulcherrima under different light regimes and temperatures.

\begin{tabular}{lccc} 
& & & \\
Light cycles & --------- & \multicolumn{3}{c}{ Temperatures $\left({ }^{\circ} \mathrm{C}\right)$-------- } \\
\cline { 2 - 4 } & 25 & 30 & $20-30$ \\
White & $43 \mathrm{aC}$ & $7 \mathrm{aA}$ & $54 \mathrm{bB}$ \\
Green & $33 \mathrm{bC}$ & $4 \mathrm{cB}$ & $64 \mathrm{aA}$ \\
Red & $33 \mathrm{bC}$ & $64 \mathrm{bA}$ & $55 \mathrm{bB}$ \\
Far red & $21 \mathrm{~dB}$ & $63 \mathrm{bA}$ & $63 \mathrm{aA}$ \\
Dark & $29 \mathrm{cA}$ & $25 \mathrm{dA}$ & $25 \mathrm{cA}$ \\
\hline
\end{tabular}

Means followed by the same letter, lowercase in the column and upper case in the row, do not differ statistically from each other, a $5 \%$ probability by the Scott-Knott test. 
is presented the obtained significant interaction between light regimes and temperatures. The highest percentage of germination was verified at $30^{\circ} \mathrm{C}$, when seeds were sown under the white light regime; however, the temperature of $25^{\circ} \mathrm{C}$ was harmful to seedlings formation.

Another relevant parameter to highlight is the influence of the temperature exerted on the germination of this species. In the treatments in which the temperature of $25^{\circ} \mathrm{C}$ was used, there was a significant decrease in the percentage of germination in relation to the treatments in which the temperature of $30^{\circ} \mathrm{C}$ was proposed.

According to Bergo et al. (2010), the ability of seeds to germinate under different environmental conditions may have useful consequences, since for some seeds, germination will occur regardless of the conditions of their environment.

The highest percentage of germination in seeds of Clitoria fairchildiana Howard occurred at $25^{\circ} \mathrm{C}$ in the green, red, and dark light regimes; at $30^{\circ} \mathrm{C}$ in white light; and at $20-30^{\circ} \mathrm{C}$ in the green and far-red lights (ALVES et al., 2012). Variations in the temperatures required by the plants species are an adaptive characteristic that gives them a high capacity to establish themselves in the field, since it allows the seeds to germinate in a greater range of temperatures (PACHECO JUNIOR et al., 2013). For the species Buchenavia tomentosa, Azevedo et al. (2015) verified a higher percentage of germination when submitted to $25^{\circ} \mathrm{C}$.

Knowledge about the ecophysiology of plant species and establishment of seedlings in the field will allow us to better understand how these plant species can develop and survive in this type of seasonal environment (NOGUEIRA et al., 2014).

The data for the germination rate index of C. pulcherrima seeds are shown in table 3. There was a higher germination index when seeds were placed at the temperature associated to the green, red and dark

Table 3 - Index seed germination speed Caesalpinia pulcherrima under different light and temperature regimes.

\begin{tabular}{lccc}
\multirow{2}{*}{ Light cycles } & \multicolumn{3}{c}{-------- Temperatures $\left({ }^{\circ} \mathrm{C}\right)$------------ } \\
\cline { 2 - 4 } & 25 & 30 & $20-30$ \\
White & $2.55 \mathrm{bA}$ & $3.02 \mathrm{aA}$ & $2.68 \mathrm{bA}$ \\
Green & $2.54 \mathrm{aA}$ & $2.64 \mathrm{aB}$ & $2.49 \mathrm{aB}$ \\
Red & $2.52 \mathrm{aA}$ & $2.79 \mathrm{aB}$ & $2.76 \mathrm{aA}$ \\
Far red & $2.42 \mathrm{bA}$ & $2.68 \mathrm{aB}$ & $2.76 \mathrm{aA}$ \\
Dark & $2.31 \mathrm{aA}$ & $2.60 \mathrm{aB}$ & $2.31 \mathrm{bB}$ \\
\hline
\end{tabular}

Means followed by the same letter, lowercase in the column and upper case in the row, do not differ statistically from each other, a $5 \%$ probability by the Scott-Knott test. light regimes at the temperature of $30^{\circ} \mathrm{C}$ favoring the germination index when the seeds in the presence of light however, at the temperature of $20-30^{\circ} \mathrm{C}$ the highest IVG was achieved in red and red-distant light regimes.

However, there are more adequate conditions for germination for each species, and the physiological characteristics of these species are different, especially regarding the presence or absence of light on the germination (MONDO et al., 2010). In seeds of Crataeva tapia L., it was observed that at $20-30^{\circ} \mathrm{C}$, the highest indexes of germination speed occurred when white, green, and red light regimes were used (GALINDO et al., 2012). Thus, the germination of seeds in response to light is an ecophysiological response of the species, which is correlated with its positioning in the successional stage of the forest (CARVALHO \& NAKAWAVA, 2012).

In order to obtain the maximum seed germination potential of a species, it is necessary to know the necessity of the factors of luminosity and temperature during this process. The root length of $\boldsymbol{C}$. pulcherrima seedlings had no significant interaction between light regimes and temperatures. Temperature of $30^{\circ} \mathrm{C}$ provided higher root length and the light regimes proved to be more efficient in the white and far-red lights table 4. Alternating temperature of $20-30^{\circ} \mathrm{C}$ provided greater length of the root of Clitoria fairchildiana in the regime of distant red light (ALVES et al., 2012). The largest root length of the Platymiscium floribundum Vog seedlings were reported at the constant temperature of $25^{\circ} \mathrm{C}$ in the distant white and red light regimes, while at the $30^{\circ} \mathrm{C}$ temperature, the primary root lengths were obtained in the distant red light regimes and in the absence of continuous light (ALVES, et al. 2016).

Shoot length of the seedlings of C.pulcherrima at constant temperatures of $25^{\circ} \mathrm{C}$ and alternated at 20 $30^{\circ} \mathrm{C}$, regardless of the light regime employed, was not favorable for the development of the seedlings. At $30^{\circ} \mathrm{C}$, the green, red, far-red, and dark light regimes provided the highest shoot lengths of the C. pucherrima (Table 5).

Table 4 - Root length of Caesalpinia pulcherrima seedlings submitted to different light and temperature regimes.

\begin{tabular}{lccc}
\hline Temperatures & Means & Light cycles & Means \\
\hline $25^{\circ} \mathrm{C}$ & $7.61 \mathrm{~b}$ & White & $7.93 \mathrm{a}$ \\
$30^{\circ} \mathrm{C}$ & $8.49 \mathrm{a}$ & Green & $7.36 \mathrm{~b}$ \\
$20-30^{\circ} \mathrm{C}$ & $7.66 \mathrm{~b}$ & Red & $7.63 \mathrm{~b}$ \\
& & Far red & $8.37 \mathrm{a}$ \\
& & Dark & $8.30 \mathrm{~b}$ \\
\hline
\end{tabular}

Averages followed by the same letter in the column are statistically equal to each other by the Tukey test at $5 \%$ significance. 
Table 5 - Length shoot of Caesalpinia pulcherrima seedlings from seeds under different light and temperature regimes.

\begin{tabular}{lccc}
\hline \multirow{2}{*}{ Light cycles } & & \multicolumn{3}{c}{------ Temperatures $\left({ }^{\circ} \mathrm{C}\right)$------------- } \\
\cline { 2 - 4 } & 25 & 30 & $20-30$ \\
White & $7.88 \mathrm{bB}$ & $10.22 \mathrm{bA}$ & $7.52 \mathrm{cB}$ \\
Green & $9.04 \mathrm{aC}$ & $10.93 \mathrm{aA}$ & $9.87 \mathrm{aB}$ \\
Red & $8.02 \mathrm{bB}$ & $11.27 \mathrm{aA}$ & $8.67 \mathrm{bB}$ \\
Far red & $9.40 \mathrm{aB}$ & $10.85 \mathrm{aA}$ & $8.70 \mathrm{bC}$ \\
Dark & $9.64 \mathrm{aB}$ & $11.35 \mathrm{aA}$ & $10.21 \mathrm{aB}$ \\
\hline
\end{tabular}

Means followed by the same letter, lowercase in the column and upper case in the row, do not differ statistically from each other, a $5 \%$ probability by the Scott-Knott test.

Thus, there is a difference in temperature requirement for the development of different parts of the seedling. Silva et al. (2014) reported for seeds of 'quixaba' [Sideroxylon obtusifolium (Roem. \& Schult.)] that the highest length of the shoot was when the seeds were at $25^{\circ} \mathrm{C}$ in the regime of white and far-red lights; at $30^{\circ} \mathrm{C}$, it was in red and far-red lights; and at $20-30^{\circ} \mathrm{C}$, it was in red, far-red, and dark light regimes.

The highest dry mass of roots of $C$. pulcherrima seedlings was found when seedlings were submitted to the temperature of $20-30^{\circ} \mathrm{C}$ in the green, red, and far-red light regimes. Thus, there must have been a greater allocation of reserves from the storage tissues and a greater incorporation of them by the embryonic axis. Similar behavior was observed at $25^{\circ} \mathrm{C}$ under a regime of white and red lights, and at $30^{\circ} \mathrm{C}$ when associated with red light, resulting in seedlings with higher dry mass (Table 6).

Table 6 - Dry mass of roots of Caesalpinia pulcherrima seedlings from seeds under different light regimes and temperatures.

\begin{tabular}{|c|c|c|c|}
\hline \multirow{2}{*}{ Light cycles } & \multicolumn{3}{|c|}{--------------Temperatures $\left({ }^{\circ} \mathrm{C}\right)----------$} \\
\hline & 25 & 30 & $20-30$ \\
\hline White & $0.0062 \mathrm{aA}$ & $0.0055 \mathrm{bB}$ & $0.005 \mathrm{bB}$ \\
\hline Green & $0.0055 \mathrm{bB}$ & $0.0062 \mathrm{aB}$ & $0.0067 \mathrm{aA}$ \\
\hline Red & $0.0067 \mathrm{aA}$ & $0.0075 \mathrm{aA}$ & $0.0072 \mathrm{aA}$ \\
\hline Far red & $0.0065 \mathrm{bA}$ & $0.0060 \mathrm{bB}$ & $0.0075 \mathrm{aA}$ \\
\hline Dark & $0.0055 \mathrm{bB}$ & $0.0057 \mathrm{bB}$ & $0.0055 \mathrm{aA}$ \\
\hline
\end{tabular}

Means followed by the same letter, lowercase in the column and upper case in the row, do not differ statistically from each other, a $5 \%$ probability by the Scott-Knott test.
Root length of Parkia pendula Willd seedlings at 25 and $30^{\circ} \mathrm{C}$ was higher compared to the others temperatures (ROSSETO et al., 2009). The length of the primary root of Clitoria fairchildiana (R.A. Howard) seedlings at $25^{\circ} \mathrm{C}$ in the green, red, and far-red light regimes was higher (ALVES et al., 2012).

Seedlings of Simira gardneriana M.R. ("pereiro-vermelho") showed lower accumulation of dry mass when the seeds were submitted to a constant temperature of $35^{\circ} \mathrm{C}$ (OLIVEIRA et al., 2016). The highest dry mass contents of the roots of Platymiscium floribundum Vog were reported in seedlings from seeds submitted to temperatures of $25^{\circ} \mathrm{C}$ in the regimes light of green, white, red distant, red and dark (ALVES, et. al., 2016).

Analyzing the data of the shoot dry mass (Table 7), it is observed that at the temperature of $25^{\circ} \mathrm{C}$ the highest dry mass content was reported in the green light regime, in turn, at $30^{\circ} \mathrm{C}$, it was noticed greater dry mass content under green and red light, whereas at $20-30^{\circ} \mathrm{C}$, it was the light regime of dark. Taking the light regimes, it is noticed that the red light at $25^{\circ} \mathrm{C}$ provided the lowest dry mass content of shoot. Initial development of Crataeva tapia L. seedlings evaluated by shoot length at $35^{\circ} \mathrm{C}$, regardless of the applied light regime, was not adequate (GALINDO et al., 2012). The highest dry mass content of the shoot of Clitoria fairchildiana (R. A. Howard) seedlings occurred at $25^{\circ} \mathrm{C}$ in the white, green, and dark light regimes. At $30^{\circ} \mathrm{C}$, in the green, far-red and dark light regimes, while at the alternated temperature of $20-30^{\circ} \mathrm{C}$, it was in the redlight regime (ALVES et al., 2012).

Table 7 - Mass shoot dry of Caesalpinia pulcherrima seedlings from seeds under different light regimes and temperatures.

\begin{tabular}{|c|c|c|c|}
\hline \multirow{2}{*}{ Light cycles } & \multicolumn{3}{|c|}{--------------Temperatures $\left({ }^{\circ} \mathrm{C}\right)-----------$} \\
\hline & 25 & 30 & $20-30$ \\
\hline White & $0.0317 \mathrm{bA}$ & $0.0335 \mathrm{bA}$ & $0.0322 \mathrm{bA}$ \\
\hline Green & $0.0350 \mathrm{aA}$ & $0.0357 \mathrm{aA}$ & $0.0322 \mathrm{bB}$ \\
\hline Red & $0.0305 \mathrm{bC}$ & $0.0362 \mathrm{aA}$ & $0.0335 \mathrm{bB}$ \\
\hline Far red & $0.0317 \mathrm{bB}$ & $0.0342 \mathrm{bA}$ & $0.0320 \mathrm{bB}$ \\
\hline Dark & $0.0340 \mathrm{aB}$ & $0.0330 \mathrm{bB}$ & $0.0362 \mathrm{aA}$ \\
\hline
\end{tabular}

Means followed by the same letter, lowercase in the column and upper case in the row, do not differ statistically from each other, a $5 \%$ probability by the Scott-Knott test. 


\section{CONCLUSION}

Seeds of $C$. pulcherrima germinate in the presence and absence of light, being considered as neutral photoblastic. Interaction between temperature and light showed that at constant temperatures of 25 and $30^{\circ} \mathrm{C}$, white light and distant red reduce the germination percentage respectively, while at the alternating temperature of $20-30^{\circ} \mathrm{C}$ the green light caused this reduction.

\section{ACKNOWLEDGEMENTS}

Authors would like to thank the Seed Analysis Laboratory, "Center for Agrarian Sciences (CCA), of Paraiba", Universidade Federal da Paraiba (UFPB).

\section{DECLARATION OF CONFLICTING INTERESTS}

The authors declared no potential conflicts of interest with respect to the research, authorship, and/or publication of this article.

\section{REFERENCES}

ABUD, H. F. et al. Morphology of seed and seedling of safflower. Revista Ciência Agronômica, Fortaleza, v.41, n.2, p.259-265, 2010. Available from: <http://www.scielo.br/scielo.php?script=sci_nlink s\&ref $=000111 \&$ pid $=S 01013122201100020000400001 \& \operatorname{lng}=p t>$. Accessed: Jul. 20, 2017. doi: 10.1590/S1806-66902010000200013.

ALVES, M. M. et al. Germination of seeds of Platymiscium floribundum Vog. (Fabaceae) under the influence of temperatures and light. Ciência Florestal, Santa Maria, v.26, n.3, p.971-978, 2016. Available from: <http://dx.doi.org/10.5902/1980509824225>. Accessed: Oct. 10, 2017. doi. 10.5902/1980509824225.

ALVES, M. M. et al. Physiological potential of Clitoria fairchildiana R. A. Howard. seeds - Fabaceae under different light regimes and temperature. Ciência Rural, Santa Maria, v.42 n.12, p.2199-2205. 2012. Available from: <www.scielo.br/ scielo.php?pid=S0103-84782012001200015\&script=sci...tlng $>$. Accessed: May 19, 2017. doi. 10.1590/0103-84782012005000118.

AZEVEDO, M. I. R. et al. Effects of substrates, light and temperature on seeds germination of Buchenavia tomentosa Eichler under laboratory conditions. Agri-environmental sciences, Palmas, v.1, n.1, p.11-21. 2015. Available from: $<$ https://revista.unitins.br/index. php/agri-environmental-sciences/article/view/42/119>. Accessed: Aug. 19, 2017. doi: 42-1-607-1-10-20160601\%20(2).

BARROSO, C. M. et al. Substratum and light on the germination of Sinningia lineata. Horticultura Brasileira, Brasília, v.28, n.2, p.236-240, 2010. Available from: <http://www.scielo.br/scielo. php?script=sci arttext\&pid=S0102-05362010000200018>. Accessed: Sept. 22 , 2017. doi. 10.1590/S0102-05362010000200018.

BERGO, C. L. et al. Light and temperature in the seed germination of long pepper (Piper hispidinervum) and monkey pepper (Piper aduncum). Revista Brasileira de Sementes, Londrina, v.32, n.3, p.170-176, 2010. Available from: <http://www.scielo.br/scielo. php?script $=$ sci_arttext\&pid=S010131222010000300019\&nrm =iso\&tlng=pt>. Accessed: Sept. 22, 2016. doi: 10.1590/S010131222010000300019 .

BRAGA, R. C. et al. Evaluation of Caesalpinia Pulcherrima endospermic gum as affinity matrices for galactose-binding lectins interaction. Brazilian Archives of Biology and Technology, v.54, n.2, p. 283-292, 2011. Available from: <http://www.scielo.br/ scielo.php?script=sci_arttext\&pid=S1516-89132011000200009>. Accessed: Sept. 22, 2016. doi: 10.1590/S1516-89132011000200009.

BRASIL. Ministério da Agricultura, Pecuária e Abastecimento. Regras para análise de sementes. Secretaria Nacional de Defesa Agropecuária. Brasília: MAPA/ACS, 395 p.2009.

CARVALHO, N. M.; NAKAGAWA, J. Sementes: ciência, tecnologia e produção. 5.ed. Jaboticabal: FUNEP, 590 p. 2012.

FERREIRA, D. F. Análises estatísticas por meio do Sisvar para Windows versão 4.0. In. Reunião anual da região brasileira da sociedade internacional de biometria, 45., 2000, São Carlos. Anais... São Carlos: SIB, 2000. p. 255-258. Available from: $<$ http://www. scielo.br/scielo.php?script=sci_nlinks\&ref=000108\&pid=S1413705 $4200300010001400015 \& \operatorname{lng}=$ en $>$. Accessed: Sept. 12, 2017.

GALINDO, E. A. et al. Germination and vigor of Crataeva tapia $\mathrm{L}$. seeds in different temperatures and light regimes. Revista Ciência Agronômica, Fortaleza; v.43, n.1, p.138-145, 2012. Available from: $<$ http://www.scielo. $\mathrm{br} / \mathrm{scielo}$.php?script=sci_arttext\&pid=S1806-66902012000100017>. Accessed: Sept. 22, 2017. doii: 10.1590/S1806-66902012000100017.

LORENZI, H. Árvores brasileiras: manual de identificação e cultivos de plantas arbóreas do Brasil. 2.ed. São Paulo: Nova Odessa, 368 p. 2009

LUZ, F. N. et al. Interference of light, temperature, depth of sowing and straw on germination and emergency of Murdannia nudiflora. Comunicata Scientiae, Bom Jesus, v.5, n.1, p.26-33, 2014. Available from: $\quad<$ https://comunicatascientiae.com.br/comunicata/article/ view/238>. Accessed: Sept. 22, 2017. doi: 238-2773-1-20(1).

MARCOS FILHO J. Fisiologia de sementes de plantas cultivadas. Piracicaba: FEALQ. 2005. 495 p.

MAGUIRE J.D. Speed of germination aid in selection and evaluation for seedling emergence and vigor. Crop Science, v. 2, n. 2 p. 176177. 1962.

MONDO, V. H. V. et al. Light and temperature effects on the seed germination of four Digitaria weed species. Revista Brasileira de Sementes, Londrina, v.32, n.1, p.131-137, 2010. Available from: $<$ www.scielo.br/pdf/rbs/v32n1/v32n1a15.pdf $>$. Accessed: Sept. 22. 2016. doi: 10.1590/S0101-31222010000100015.

MORITZ, A.; ORTIZ, T. A.; ASSARI, L. S. T. Light and temperature on seed germination of Sinningia leucotricha. Applied Research \& Agrotechnology, Guarapuava, v.8, n.1, p.63-68. 2015. Available from: $<\mathrm{http} / / /$ revistas.unicentro.br/index.php/repaa/article/view/3205>. Accessed: Jan. 22, 2016. doi: 10.5935/paet.v8.n1.07.

NOGUEIRA, F. C. B. et al. The effect of the temperature and light on the seed germination of Dalbergia cearensis Ducke. Revista Ciência Florestal, Santa Maria, v.24, n.4, p.997-1007. 2014. Available from: $<$ http://dx.doi.org/10.5902/1980509816613>. Accessed: Apr. 22, 2017. doi: 10.1590/1980-509820142404019. 
OLIVEIRA, L. M. et al. Pre-germinated treatments in seeds of Caesalpinia pulcherrima (L.) Sw. - leguminosae. Revista Caatinga, Mossoró, v.23, n.1, p.71-76, 2010. Available from: $<$ http://periodicos. ufersa.edu.br/revistas/index.php/sistema/article/view/1476>. Accessed: Sept. 22, 2016. doi: org/html/2371/237117582011.

OLIVEIRA, F. N. et al. Temperature and substrate on the germination of seeds of Simira gardneriana M. R. Barbosa \& Peixoto. Revista Ciência Agronômica, Fortaleza, v.47, n.4, p.658-666, 2016. Available from: <http://www.scielo.br/pdf/rca/v47n4/1806-6690rca-47-04-0658.pdf>. Accessed: May. 12, 2017.

PACHECO JUNIOR, F. S. J. B. et al. Germination and vigor of longpepper seeds (Piper hispidinervum) as a function of temperature and light. Revista Ciência Agronômica, Fortaleza, v.44, n.2, p.325-333. 2013. Available from: <http://www.scielo.br/scielo.php?pid=S1806 $66902013000200015 \&$ script $=$ sci abstract\&tlng=t $>$. Accessed: Apr 20, 2017. doi: 10.1590/S1806-66902013000200015.

ROSSETO, J. et al. Germination of Parkia pendula (Willd.) Benth. ex Walp. (fabaceae) seeds in different temperatures. Revista
Árvore, Viçosa, v.33, n.1, p.47-55. 2009. Available from: <http:// www.scielo.br/pdf/rarv/v33n1/v33n1a06.pdf>. Accessed: Nov. 18, 2016. doi: 10.1590/S0100-67622009000100006.

RIBEIRO, C. A. D. et al. Fatores que afetam a germinação das sementes e a biomassa de plântulas de Tabebuia heptaphylla. Revista Floresta, Curitiba, v.42, n.1, p.161 - 68, 2012. Available from: $<$ http://revistas.ufpr.br/floresta/article/viewFile/26312/17513>. Accessed: Apr. 19, 2017. doi: 10.5380/rf.v42i1.26312.

SILVA, K. B. et al. Influence of light and temperature in the germination of quixaba seeds. Revista Agropecuária Técnica, v.35, n.1, p.13-22, 2014. Available from: <http://periodicos.ufpb. br/index.php/at/article/viewFile/10254/10707>. Accessed: Apr. 18, 2017. doi: org/10.25066/agrotec.v35i1.10254.

VÁZQUEZ-YANES, C. \& OROZCO-SEGOVIA, A. Ecological significance of light controlled seed germination in two contrasting tropical habitats. Oecologia, v.83, n.2, p.171-175, 1990. Available from: $<$ https://www.ncbi.nlm.nih.gov/pubmed/22160107>. Accessed: Apr. 19, 2017. doi: 10.1007/BF00317748. 